\title{
INDUSTRY “FISHING AND AQUACULTURE” AS ECONOMIC UNIT IN THE BALTIC STATES AND FINLAND
}

\author{
Andrejs Jaunzems, Ilze Balode \\ Ventspils University of Applied Sciences, Latvia \\ jaunzems@venta.lv
}

\begin{abstract}
The research is devoted to the industry "Fishing and aquaculture" as an economic unit in Estonia, Finland, Latvia, Lithuania. With help of the input-output mathematical model, mathematical analysis, and adequate software we carry out the economical and technological analysis of the industry "Fishing and aquaculture". The analysis is provided in the comparative aspect (comparing Estonia, Finland, Latvia, Lithuania) and in the dynamic aspect (using statistical information for 15 years). The statistical information in current research is the National Input-Output Tables for the 2000-2014 available via the World Input-Output Database. The original modification of the classical input-output model created by Jaunzems (2017), especially for World Input-Output Database's information structure, allows us to calculate and to interpret line of economical and technological indicators: technological interindustry coefficients, Leontief inverse, monetary allocation coefficients, Ghosh inverse. All economical and technological interpretations of indicators are based on the mathematical connections resulted from the input-output model. According to the International Standard Industrial Classification of All Economic Activities, agriculture is divided into three industries "Crop and animal production, hunting and related service activities", "Forestry and logging", "Fishing and aquaculture". The authors have already provided the comparative dynamic analysis of the industries' "Crop and animal production, hunting and related service activities", "Forestry and logging" economies (ERDEV: 2018, 2019). The systemized and founded conclusions about whole agriculture will be presented to the Agriculture Ministry of Latvia for the more detailed analysis and proper actions elaboration.
\end{abstract}

Keywords: fishing and aquaculture, input-output, interindustry coefficients, Leontief inverse, allocation coefficients, Ghosh inverse.

\section{Introduction}

The Latin motto of Food and Agriculture Organization of the United Nations (FAO) sounds fiat panis (let there be bread) - mankind exists thanks to agriculture.

According to the International Standard Industrial Classification of All Economic Activities (ISIC), three industries of agriculture can be distinguished: "Crop and animal production, hunting and related service activities", "Forestry and logging", "Fishing and aquaculture". The authors have already completed the comparative dynamic input-output analysis of two industries' "Crop and animal production, hunting and related service activities", "Forestry and logging" (ERDEV: 2018, 2019) in Estonia, Finland, Latvia and Lithuania during the time period from 2000 until 2014. This paper is dedicated to the industry "Fishing and aquaculture" as an economic unit in Estonia, Finland, Latvia, and Lithuania. By means of the input-output mathematical model, mathematical analysis, and adequate software we intend to provide research of the economical and technological indicators of the industry "Fishing and aquaculture" as producer and seller from the comparative and dynamic viewpoint. The comparative aspect stands for comparison of the industry "Fishing and aquaculture", which operates in Estonia, Finland, Latvia, Lithuania, but the dynamic aspect is carried out using statistical data for 15 years.

A lot of information about industry "Fishing and aquaculture" worldwide is available. See, for example, materials of "FAO Fisheries and Aquaculture Department": http://www.fao.org/fishery/facp/LVA/en.

The issues of value added creation in fishing and aquaculture industry are investigated in number of recent papers, for instance, in the papers [1-7]. The Input-Output models are applied in The InputOutput analysis of blue industries: comparative study of Estonia and Finland (Ashyrov, Paas, Tverdostup 2018) and in Economic Performance Analysis of Selected Blue Economy Sectors in Estonia and Finland (Tverdostup, Maryna \& Paas, Tiiu 2019). The authors analyse the inter-industry linkages by means of the Input-Output methodology.

The following conclusion in the paper Characteristics of the fishing industry in Latvia (Proskina, L., Pilvere, I., Nipers, A., Silovs, M. 2018) arises interest to the authors of this paper: "In 2016 in Latvia, the top 10 fishing enterprises had a turnover of EUR $58.2 \mathrm{mln}$., which increased by $60.7 \%$ 
compared with 2014 and by $27.7 \%$ compared with 2015. In 2016, among the top 10 enterprises in terms of net turnover, only four made profit, whereas six suffered losses, and two had quite high profit margins. In 2016, the top 10 fishing enterprises employed 516 individuals and demonstrated different levels of labour productivity. This means that fishing enterprises are operating in an intensive competitive environment and there is a need to analyse the factors affecting financial performance in order to achieve better results".

Note: all tables and all figures in the current paper are created by the authors applying NIOT data, mathematical models and Microsoft Excel tools.

\section{Materials and methods}

The statistical data for our research are the National Input-Output Tables for the Period 20002014 (NIOT) available from the World Input-Output Database WIOD (www.wiod.org). NIOT are presented in current prices, expressed in millions of US dollars. The Input-Output tables have an industry-by-industry format and reveal the economical and technological relationships between industries. We consider information of NIOT as a trustworthy source of information.

In NIOT (according the United Nations) three-letter codes are applied: EST for Estonia, FIN for Finland, LVA for Latvia, LTU for Lithuania. Following the United Nations industry classification system "International Standard Industrial Classification of All Economic Activities (ISIC)"; the national economy is divided in 56 sectors. The products in NIOT are classified according to the statistical classification of products by activity, abbreviated as CPA. The NIOT classification of products (goods and services) covers 56 product categories corresponding to the primary outputs of 56 industries. As it was mentioned before, following the International Standard Industrial Classification of All Economic Activities (ISIC), revision No. 4, agriculture (A) is classified into three industries A01 (Crop and animal production, hunting and related service activities), A02 (Forestry and logging), A03 (Fishing and aquaculture).

The authors have already performed the comparative dynamic input-output analysis of the industries A01 and A02 in Estonia, Finland, Latvia and Lithuania, during the time period from 2000 until 2014. In the papers by Jaunzems (2017), Jaunzems (2018), Jaunzems, Balode (2018) materials and methods of the holistic research of the national economy by means of input-output methodology are explained. In the papers [8-10] the original Input-Output model is adapted for NIOT and is offered. Also, the research methodology was approbated. In these papers we have expounded in detail the materials and theoretical methods of the national economy's holistic investigation by means of the input-output methodology. We have also illustrated theoretical content with some simple numerical examples, in order for the paper to be more understandable. We kindly appeal to the reader to get to know the chapter "Materials and methods" in the open access papers [8-10].

Let us mention only the general input-output ideas. The models of input-output kind are traced back to the French economist François Quesnay (1694-1774) with his "Tableau économique" (Economic Table), published in 1758. French mathematical economist Marie-Esprit-Léon Walras (1834-1910) is the author the general equilibrium theory [11;12]. In our research we apply the basic ideas of Leontief [13] and Gosh [14]. The modern Input-Output theory is available, for example, in the notable book "Input-Output Analysis. Foundations and Extensions" by Ronald E. Miller, Peter D. Blair [15]. The paper [16] and Springer Proceedings in Business and Economics [17] are useful for us. In general, a lot of materials about current input-output theory and its applications are available.

Behind the input-output framework, there is an assumption that the open economy consists of $n$ sectors (industries). Thijs ten Raa (2019) [18] interprets the industries as "machines transforming factor inputs into value added". In other words, industries have multiple (factor) inputs, but essentially a single "output", namely value added. We interpret the industry differently. We regard the industry as the abstract subject "producer-seller", which transforms multiple factor inputs into gross output that is sold and generates value added. Besides that, we distinguish the industry's output sales as intermediate consumptions and output sales as final demand purchases. We dissociate also the industry's intermediate consumption purchases from domestic industries from intermediate consumption as imported products purchases. The result of industry's operations depends of a numerous external and internal factors. 
Let us emphasize that we are interested in value added created by industry. Value added created by an industry means: "Value added (gross) is total output less the intermediate consumption" (European Central Bank (ECB) Glossary [20]). The contents of industry's value added are expressed by well known formula: value added = compensation of employees + gross operating surplus + net taxes on production and imports. In our opinion, the input-output approach is a better way to study the basic economic indicators of open national economy in its interaction in order to gain understanding how the system works. The investigation of the national economy by means of input-output model is essentially more structured than general macroeconomic investigation. Besides all that, the inputoutput studies must be considered as the step towards detailed microeconomic studies of the behaviour of the owners of firms in business political, economical, social, technological, international, legal, bioenvironmental environment (PESTILB).

\section{Results and discussion}

In order to get a complete view on the industry's A03 (Fishing and aquaculture) economics in EST, FIN, LVA, LTU, array of indicators are calculated. It should be emphasized that the interpretations of the indicators used are based on the holistic mathematical relationships resulting from the Input-Output model as a whole. The industries in the International Standard Industrial Classification are strictly defined and internationally recognized. It is handy to use the NIOT code of industries in the text. The codes and descriptions used in NIOT are provided in the paper [9], Table 7. We recommend to employ the NIOT codes on a regular basis for more unified and precise scientific understanding of the meaning of each industry.

1. Let us observe that in the Baltic States and Finland the industry A03 (Fishing and aquaculture) is one of the smallest (see Table 1). In Latvia, in 2014 industry's A03 gross output equals to only $0.12 \%$ of the national economy total gross output 64725.66. In Finland, industry's A03 gross output equals to only $0.05 \%$ of the national economy total gross output. (Values are measured in millions of US dollars.)

Ten smallest Latvian industries measured by the current industry's gross output as percentage of total gross output: $[G O($ industry) / $G O($ total $)] \cdot 100 ; 2014$

\begin{tabular}{|c|c|c|c|c|}
\hline Code & EST & FIN & LVA & LTU \\
\hline C19 & 0.70 & 2.49 & $\mathbf{0 . 0 1}$ & 9.73 \\
\hline A03 & $\mathbf{0 . 2 0}$ & $\mathbf{0 . 0 5}$ & $\mathbf{0 . 1 2}$ & $\mathbf{0 . 0 7}$ \\
\hline E36 & 0.28 & 0.18 & $\mathbf{0 . 1 5}$ & 0.25 \\
\hline C30 & 0.16 & 0.42 & $\mathbf{0 . 2 0}$ & 0.27 \\
\hline J58 & 0.33 & 0.82 & $\mathbf{0 . 2 5}$ & 0.27 \\
\hline C29 & 0.76 & 0.38 & $\mathbf{0 . 2 7}$ & 0.34 \\
\hline H50 & 1.21 & 0.66 & $\mathbf{0 . 2 8}$ & 0.28 \\
\hline C17 & 0.51 & 3.38 & $\mathbf{0 . 2 9}$ & 0.62 \\
\hline J59_J60 & 0.43 & 0.46 & $\mathbf{0 . 2 9}$ & 0.22 \\
\hline
\end{tabular}

2. Excerpts from the NIOT 2014, which cover industry's A03 (Fishing and aquaculture) expenditures and revenues in current prices, expressed in millions of US dollars.

Tables 2 and 3 contain the general indicators that describe A03 intermediate consumption.

Industry's "Fishing and aquaculture" expenditures (in millions of USD)

Table 2 in EST, FIN, LVA, LTU

\begin{tabular}{|c|l|c|c|c|r|}
\hline Code & \multicolumn{1}{|c|}{ Description } & EST & FIN & LVA & LTU \\
\hline- & Intermediate consumption (domestic) & 29.67 & 43.54 & 26.32 & 26.96 \\
\hline- & Intermediate consumption (imports) & 21.40 & 40.26 & 18.40 & 6.03 \\
\hline$I I \_f o b$ & Total intermediate consumption & 51.07 & 83.80 & 44.72 & 32.99 \\
\hline$G V A$ & Gross value added at basic prices & 57.89 & 157.98 & 34.58 & 30.97 \\
\hline$V A$ & Net value added at basic prices & 53.70 & 151.45 & 31.83 & 29.94 \\
\hline$G O$ & Output at basic prices & 108.97 & 241.79 & 79.30 & 63.97 \\
\hline
\end{tabular}


Industry's "Fishing and aquaculture" expenditures in EST, FIN, LVA, LTU

Table 3 with respect to monetary unit of output

\begin{tabular}{|c|l|c|c|c|c|}
\hline Code & \multicolumn{1}{|c|}{ Description } & EST & FIN & LVA & LTU \\
\hline- & Intermediate consumption (domestic) & 0.2723 & 0.1801 & 0.3319 & 0.4214 \\
\hline- & Intermediate consumption (imports) & 0.1964 & 0.1665 & 0.2320 & 0.0943 \\
\hline$I I \_f o b$ & Total intermediate consumption & 0.4687 & 0.3466 & 0.5639 & 0.5157 \\
\hline$G V A$ & Gross value added at basic prices & 0.5312 & 0.6534 & 0.4361 & 0.4841 \\
\hline$V A$ & Net value added at basic prices & 0.4928 & 0.6264 & 0.4014 & 0.4680 \\
\hline$G O$ & Output at basic prices & 1.0 & 1.0 & 1.0 & 1.0 \\
\hline
\end{tabular}

Table 2 shows the scale of the industry A03 operating in the countries under concern. Latvia's A03 gross output volume 79.30 means that the Latvia's A03 has potential to increase its gross output.

Table 3 gives us the first sign about Latvian A03 inefficiency: the total intermediate consumption 0.5693 per monetary unit of gross output is sufficiently larger than in EST, FIN, LTU. As a result, the net value added 0.4014 is considerably smaller. What is the reason? We are going to examine the intermediate consumption in A03 in detail.

Tables 4 and 5 contain general indicators of A03 (Fishing and aquaculture) products' final demand allocation in 2014.

Table 4

Industry's A03 final demand in EST, FIN, LVA, LTU

\begin{tabular}{|c|c|c|c|c|c|c|c|c|}
\hline Code & Intermediate sales & $\boldsymbol{C O N S \_ h}$ & $\boldsymbol{C O N S \_ n p}$ & $\boldsymbol{C O N S \_ g}$ & $\boldsymbol{G F C F}$ & $\boldsymbol{I N V E N}$ & $\boldsymbol{E X P}$ & $\boldsymbol{G O}$ \\
\hline EST & 59.42 & 8.85 & 0.00 & 0.00 & 0.02 & 11.01 & 29.67 & 108.97 \\
\hline FIN & 131.14 & 71.03 & 0.00 & 0.00 & 0.00 & 0.07 & 39.54 & 241.79 \\
\hline LVA & 21.47 & 18.36 & 0.03 & 0.58 & 0.03 & 0.00 & 38.83 & 79.30 \\
\hline LTU & 37.61 & 4.96 & 0.00 & 0.14 & 0.04 & 4.09 & 17.13 & 63.97 \\
\hline
\end{tabular}

Code and Description:

CONS_h (Final consumption expenditure by households);

CONS_g (Final consumption expenditure by government);

CONS_np (Final consumption expenditure by non-profit organisations serving households (NPISH));

GFCF (Gross fixed capital formation); INVEN (Changes in inventories and valuables);

EXP (Exports); GO (Gross output).

Table 5

Industry's A03 final demand in EST, FIN, LVA, LTU with respect to monetary unit of output

\begin{tabular}{|c|c|c|c|c|c|c|c|c|}
\hline Code & Intermediate sales & $\boldsymbol{C O N S \_ h}$ & $\boldsymbol{C O N S \_ n p}$ & $\boldsymbol{C O N S \_ g}$ & $\boldsymbol{G F C F}$ & $\boldsymbol{I N V E N}$ & $\boldsymbol{E X P}$ & $\boldsymbol{G O}$ \\
\hline EST & 0.5453 & 0.0812 & 0.0000 & 0.0000 & 0.0002 & 0.1010 & 0.2723 & 1 \\
\hline FIN & 0.5424 & 0.2938 & 0.0000 & 0.0000 & 0.0000 & 0.0003 & 0.1635 & 1 \\
\hline LVA & 0.2707 & 0.2315 & 0.0004 & 0.0073 & 0.0004 & 0.0000 & 0.4897 & 1 \\
\hline LTU & 0.5879 & 0.0775 & 0.0000 & 0.0022 & 0.0006 & 0.0639 & 0.2678 & 1 \\
\hline
\end{tabular}

Table 5 reveals notable differences in intermediate sales of A03 product in LVA and other countries of reference: 0.2707 as compared to $0.5453 ; 0.5424 ; 0.5879$. One of the reasons that is easily observable is the difference in relatively small purchases of A03 product by industry I (Accommodation and food service activities). Industry I bought (with respect to one monetary unit of A03 gross output, see table 8): in EST 0.1238; in FIN 0.1741; in LVA 0.0065; in LTU 0.0006.

Intermediate sales of industry A03 in LTU amounts to 0.5879 because of industry's C10-C12 (Manufacture of food products, beverages and tobacco products) relatively huge purchases 0.5438 .

Let us note that in our previous studies we have observed that the industry I (Accommodation and food service activities) in FIN is an active buyer of domestic industry's A01 (Crop and animal production, hunting and related service activities) products. In order to explain the difference, further examination of industry's "Accommodation and food service activities" economics is necessary. 
FIN and LVA differ from EST and LTU with respect to the industry's A03 (Fishing and aquaculture) product purchases from the CONS_h (Final consumption expenditure by households).

In order to perform the industry's economic analysis, it is purposive to divide the industry's output sales as final demand purchases into two groups: real-market sales and non-market sales.

Real-market purchases consist of from CONS_h (Final consumption expenditure by households) and from EXP (Exports). Purchases made from non-market institutions CONS_g (Final consumption expenditure by government) and GFCF (Gross fixed capital formation) mainly consist of grants. By definition, a grant is some non-repayable amount of money that a government or other institution presents to an individual or to an organization for a particular manipulative purpose.

Let us note that in FIN purchases by CONS_h and GFCF equal zero, but in LVA we have CONS_h $=0.0073 ; G F C F=0.0004$.

Figure 1 depicts the dynamics of export. It is worth to stress that in 2014 industry's A03 (Fishing and aquaculture) LVA exports equal to 0.4897 with respect to each monetary unit of gross output.

The small EXP in FIN, in turn, witness about socio-economic orientation of Finland's A03, which does not qualify as a significant A03 product exporter.

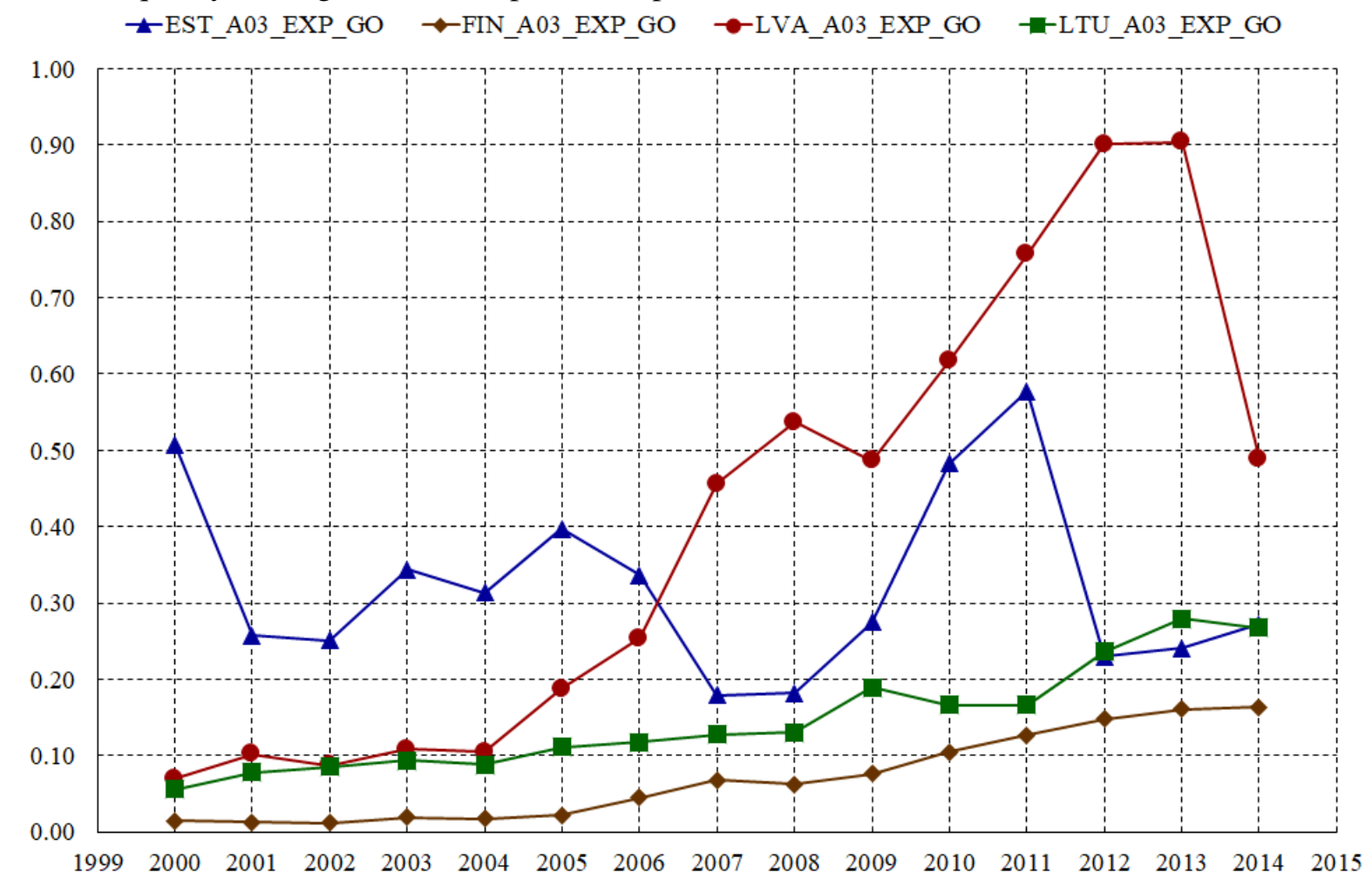

Fig. 1. Dynamics of the industry's A03 exports as share of A03 gross output in EST, FIN, LVA, LTU in 2000-2014

3. Dynamics of the industry's A03 (Fishing and aquaculture) value added as part of gross output in EST, FIN, LVA, LTU (2000-2014).

Figure 2 depicts the time series of industry's A03 value added as part of gross output in EST, FIN, LVA, LTU for the period 2000-2014. Our attention is focused on the Latvian graph with its decreasing shape from 2009.

Figure 3 depicts the trends in a functional form $v=a \cdot \tau^{b}+c$ for each of time series for the latest six years (2009-2014). Let us note that such functional form of trendline is flexible and informative, but we have not encountered such form of trendline in the latest scientific papers. 


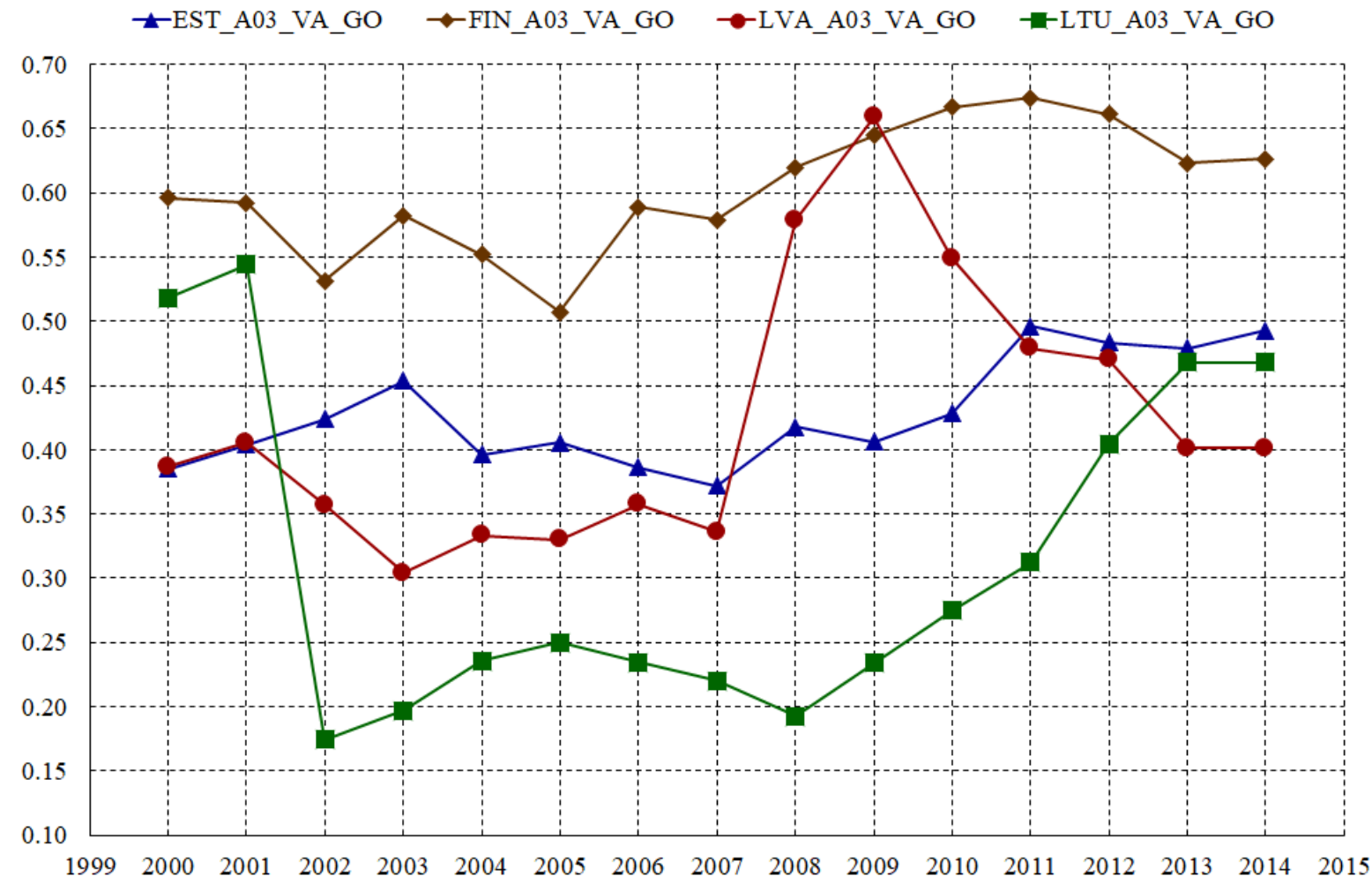

Fig. 2. Dynamics of A03 value added as part of gross output in EST, FIN, LVA, LTU in 2000-2014

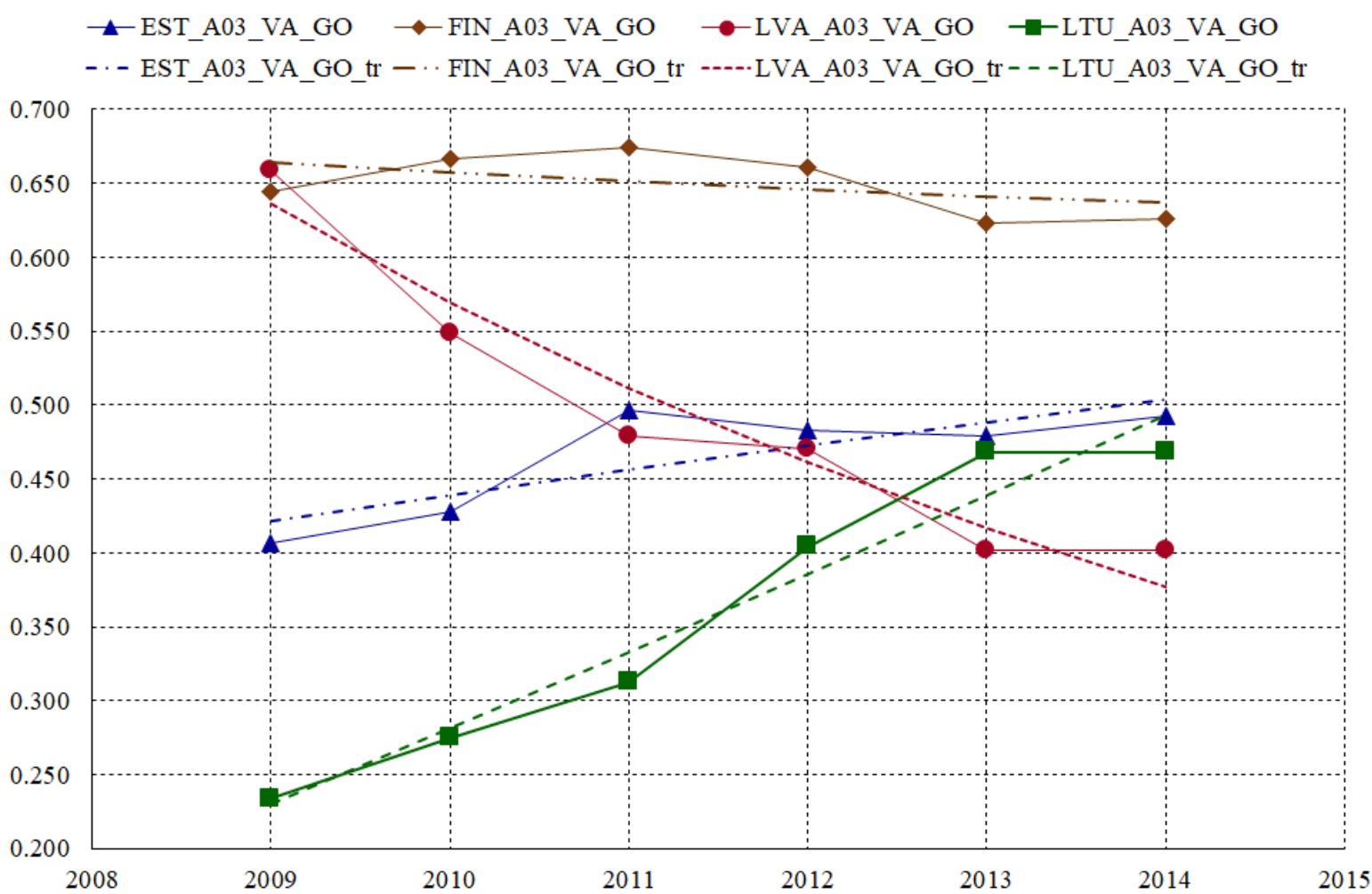

Fig. 3. Trends in a functional form $v=a \cdot \tau^{b}+c$ for value added of industry A03 as part of gross output (2009-2014)

With help of such trends we classify the shape of dynamics of A03 value added: increasing convex, increasing concave, decreasing convex, decreasing concave (table 6). We consider the increasing convex trend as a better trend. We regard the decreasing concave trend as the worst trend. Increasing the concave trend, of course, is better than decreasing the concave trend. The comparative 
approach allows us to recognize notable differences in the shape of value added trends in the industry "Fishing and aquaculture" in Estonia, Finland, Latvia and Lithuania.

Table 6

Trend lines in the functional form $v=a \cdot \tau^{b}+c, \tau=t-1998, t \in[2009 ; 2014]$. Values of the derivatives $v^{\prime}=a \cdot b \cdot \tau^{b-1} ; v^{\prime \prime}=a \cdot b \cdot(b-1) \cdot \tau^{b-2}$ in 2014

\begin{tabular}{|c|c|c|c|c|c|c|c|}
\hline A03 & a & b & c & $\uparrow$ or $\downarrow$ & $\cap$ or $\cup$ & $\boldsymbol{v}^{\prime}(\mathbf{2 0 1 4})$ & $\boldsymbol{v}^{\prime \prime}(\mathbf{2 0 1 4})$ \\
\hline EST & 0.11 & 0.51 & 0.03 & increasing & concave & 0.0155 & -0.0005 \\
\hline FIN & 0.51 & -0.41 & 0.47 & decreasing & convex & -0.0046 & 0.0004 \\
\hline LVA & 6.43 & -0.76 & -0.41 & decreasing & convex & -0.0418 & 0.0049 \\
\hline LTU & 0.03 & 1.21 & -0.23 & increasing & concave & 0.0537 & 0.0007 \\
\hline
\end{tabular}

4. Comparison and analysis of intermediate consumption.

Table 7 contains two arranged (from largest to smallest) excerpts from the total A03 intermediate consumption matrix (2014): arrangement by LVA indicators and arrangement by FIN indicators. We observe total distinction in the ten largest total intermediate consumptions (domestic plus imported purchases) per monetary unit of total output. In order to explain the difference, further examination is needed.

Table 7

Industry's A03 ten biggest input (domestic plus imported) indicators in LVA and FIN (2014) (components of the vectors $A_{{ }_{j}}:=D_{r_{j}}+M_{r_{j}}$ )

\begin{tabular}{|c|c|c|c|c|}
\hline Code & EST & FIN & LVA & LTU \\
\hline C19 & 0.1174 & 0.0156 & $\mathbf{0 . 1 0 8 5}$ & 0.0383 \\
\hline G46 & 0.0124 & 0.0086 & $\mathbf{0 . 0 7 1 2}$ & 0.0082 \\
\hline C10-C12 & 0.0135 & 0.0158 & $\mathbf{0 . 0 4 7 8}$ & 0.0038 \\
\hline A03 & 0.0042 & 0.2380 & $\mathbf{0 . 0 4 1 7}$ & 0.0040 \\
\hline H49 & 0.0044 & 0.0022 & $\mathbf{0 . 0 3 6 3}$ & 0.0133 \\
\hline D35 & 0.0091 & 0.0122 & $\mathbf{0 . 0 3 4 5}$ & 0.0094 \\
\hline C33 & 0.0606 & 0.0039 & $\mathbf{0 . 0 2 9 2}$ & 0.1147 \\
\hline M69_M70 & 0.0167 & 0.0027 & $\mathbf{0 . 0 2 7 6}$ & 0.0013 \\
\hline G47 & 0.0368 & 0.0075 & $\mathbf{0 . 0 2 1 9}$ & 0.0042 \\
\hline C30 & 0.0004 & 0.0003 & $\mathbf{0 . 0 1 9 1}$ & 0.0054 \\
\hline DBL & 0.4687 & 0.3466 & 0.5640 & 0.5158 \\
\hline
\end{tabular}

\begin{tabular}{|c|c|c|c|c|}
\hline Code & EST & FIN & LVA & LTU \\
\hline A03 & 0.0042 & $\mathbf{0 . 2 3 8 0}$ & 0.0417 & 0.0040 \\
\hline C10-C12 & 0.0135 & $\mathbf{0 . 0 1 5 8}$ & 0.0478 & 0.0038 \\
\hline C19 & 0.1174 & $\mathbf{0 . 0 1 5 6}$ & 0.1085 & 0.0383 \\
\hline D35 & 0.0091 & $\mathbf{0 . 0 1 2 2}$ & 0.0345 & 0.0094 \\
\hline G46 & 0.0124 & $\mathbf{0 . 0 0 8 6}$ & 0.0712 & 0.0082 \\
\hline G47 & 0.0368 & $\mathbf{0 . 0 0 7 5}$ & 0.0219 & 0.0042 \\
\hline A01 & 0.0006 & $\mathbf{0 . 0 0 7 4}$ & 0.0189 & 0.0003 \\
\hline R_S + T + U & 0.0015 & $\mathbf{0 . 0 0 6 0}$ & 0.0007 & 0.0012 \\
\hline C33 & 0.0606 & $\mathbf{0 . 0 0 3 9}$ & 0.0292 & 0.1147 \\
\hline M69_M70 & 0.0167 & $\mathbf{0 . 0 0 2 7}$ & 0.0276 & 0.0013 \\
\hline
\end{tabular}

We recognize that the Latvian A03 (Fishing and aquaculture) intermediate consumption (when compared with the referred countries) of products is notably bigger for the following industries: C19 (Manufacture of coke and refined petroleum products), G46 (Wholesale trade, except of motor vehicles and motorcycles), H49 (Land transport and transport via pipelines ), D35 (Electricity, gas, steam and air conditioning supply).

The gaudy inefficiency of Latvian A03 management is obvious. The purchases from industry M69_M70 (Legal and accounting activities; activities of head offices; management consultancy activities) and from industry C30 (Manufacture of other transport equipment) are especially surprising.

Let us compare Figures 4 and 5. These figures show a significant fact. Opposite to FIN, the Latvian A03 uses less products of A03: 0.2380 as compared to 0.0417. At the same time, the Latvian A03 uses more products of C10-C12 (Manufacture of food products, beverages and tobacco products): 0.0478 as compared to 0.0158 .

Figures 6, 7, 8 depict the time series of above intermediate consumption per monetary unit of gross output.

Figure 7 demonstrates notable differences in the intermediate expenses relating to D35 (Electricity, gas, steam and air conditioning supply). In 2014, in LVA intermediate product cost of the D35 is 0.0345 with respect to one monetary unit of gross output. At the same time, in EST this indicator is 0.0091, in FIN it equals to 0.0122, in LTU - 0.0094. 


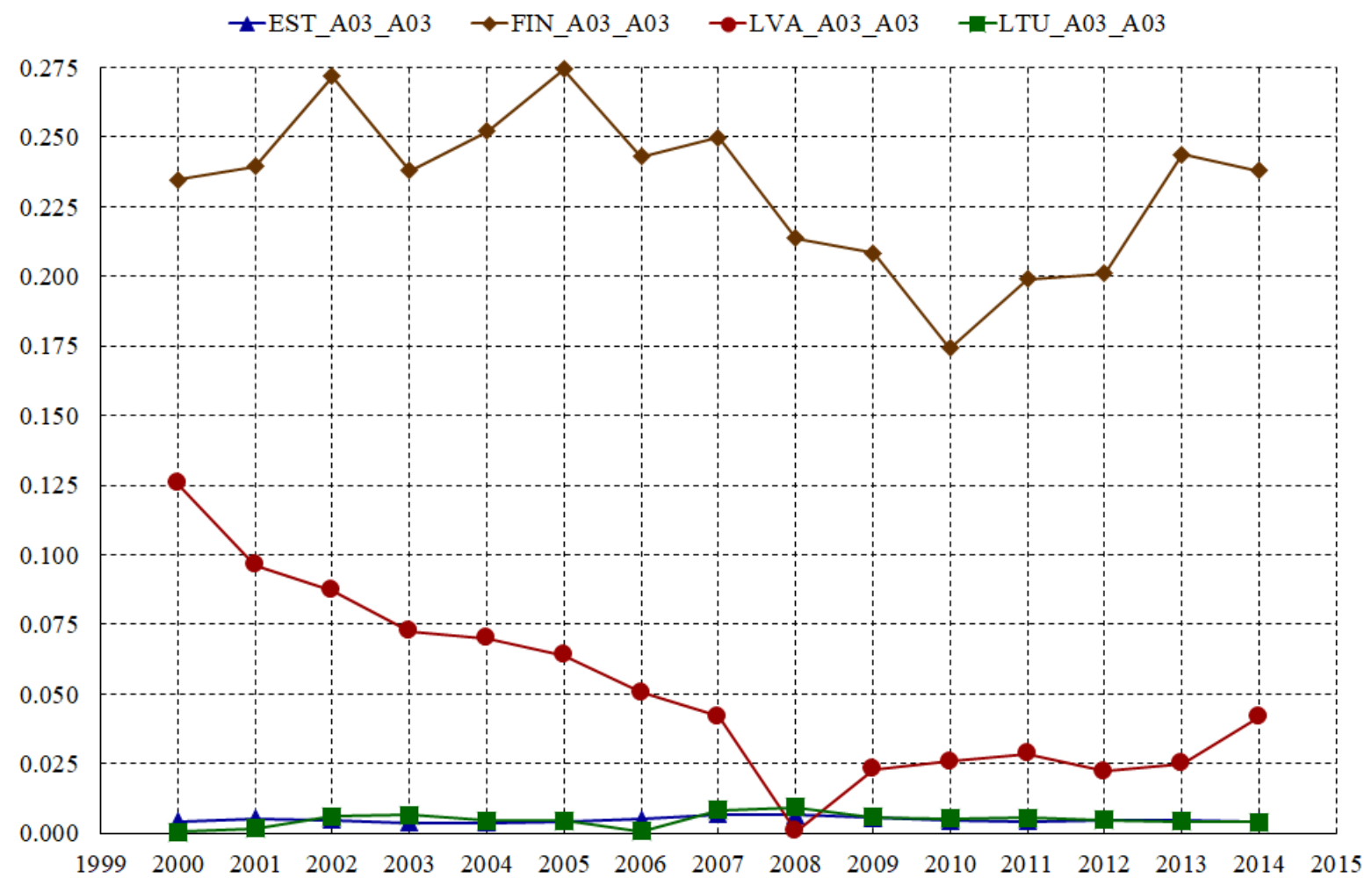

Fig. 4. Dynamics of A03 product intermediate consumption as part of A03 one monetary unit gross output

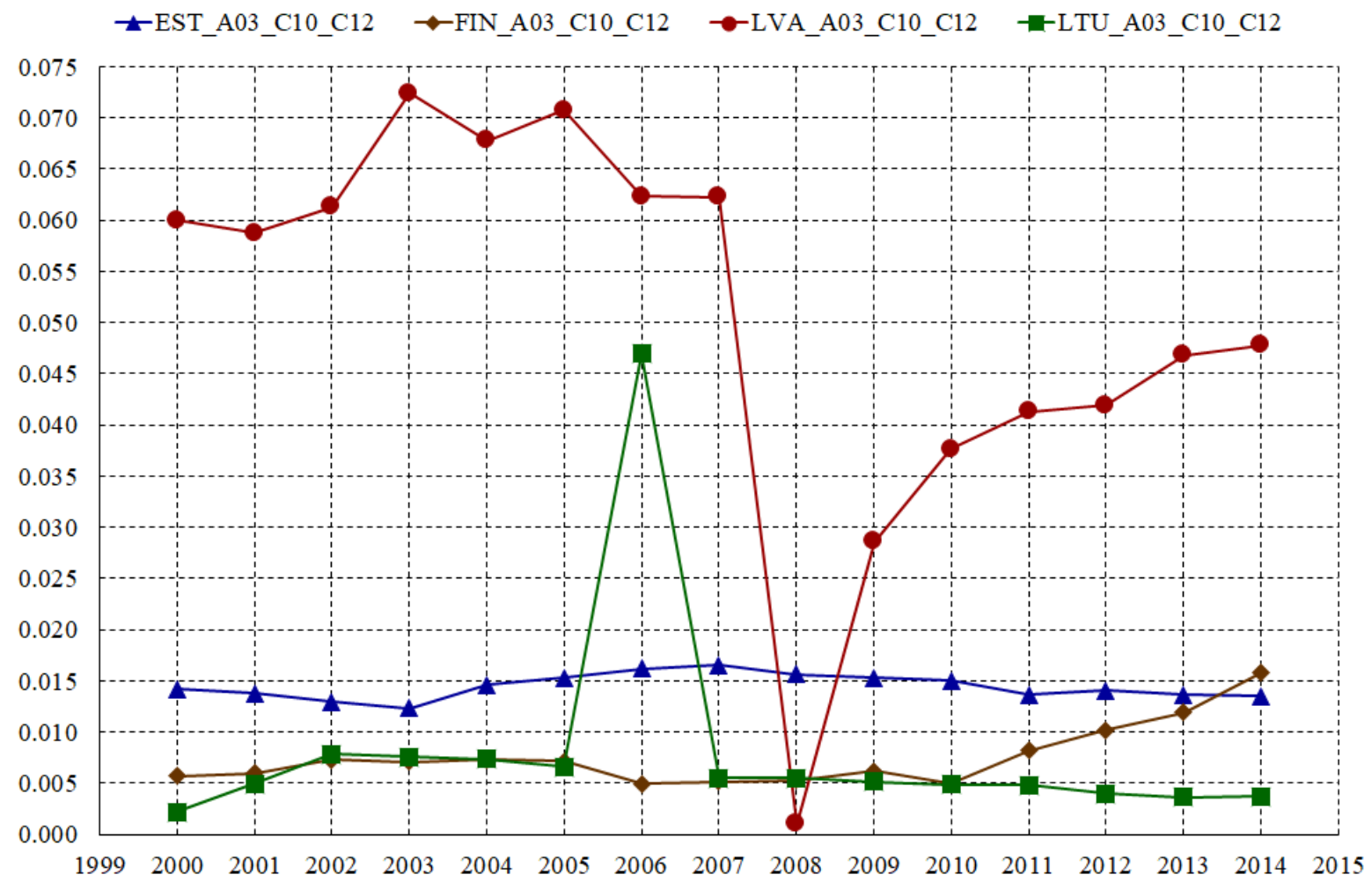

Fig. 5. Dynamics of industry's C10-C12 (Manufacture of food products, beverages and tobacco products) product intermediate consumption as part of A03 one monetary unit gross output

It is not surprising that purchases of D35 (Electricity, gas, steam and air conditioning supply) in LVA are many times larger than in other countries of reference. Indeed, the Latvian mandatory procurement public service obligation fee (in Latvian - obligātā iepirkuma komponente $(\mathrm{OIK})$ ] 
undermines competitiveness of the Latvian economy. This is a bad sign for Latvian A03 competitive power. After the parliamentary (Saeima) elections of 2018, the new political forces called OIK a fraud.

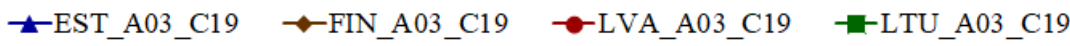

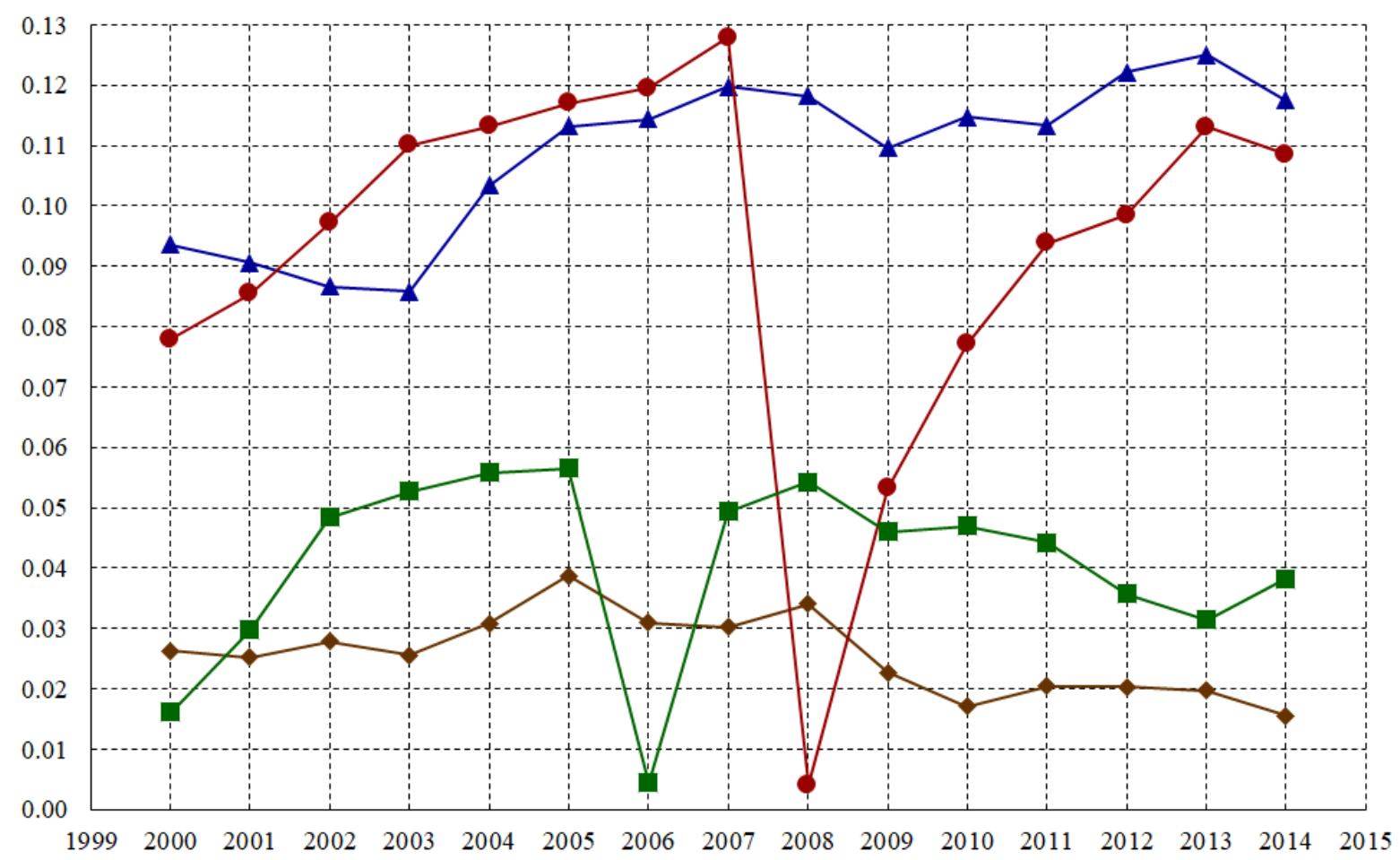

Fig. 6. Dynamics of industry's C19 (Manufacture of coke and refined petroleum products) product intermediate consumption as part of $\mathrm{A03}$ one monetary unit gross output

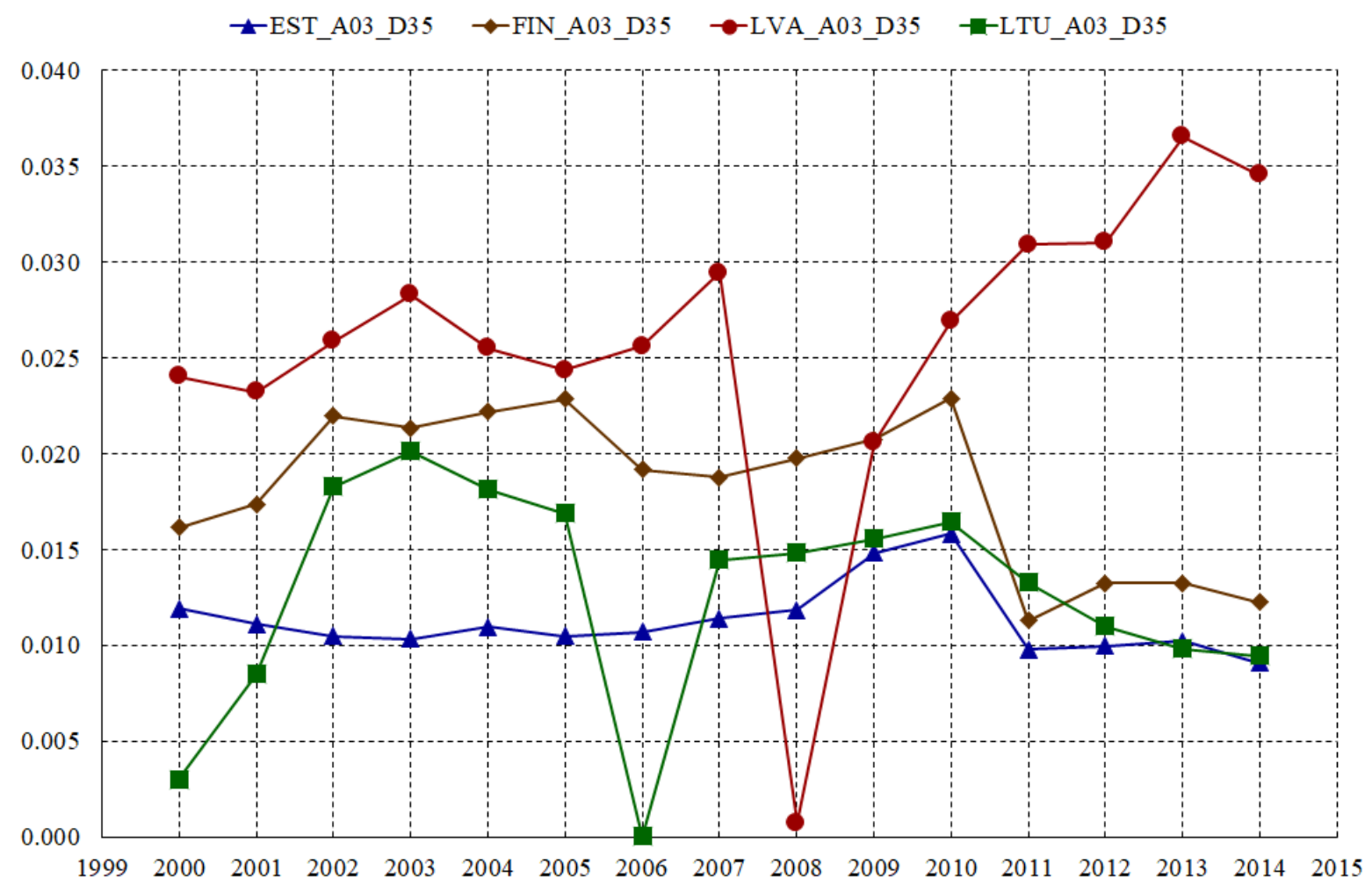

Fig. 7. Dynamics of industry's D35 (Electricity, gas, steam and air conditioning supply) product intermediate consumption as part of $\mathrm{A03}$ one monetary unit gross output 


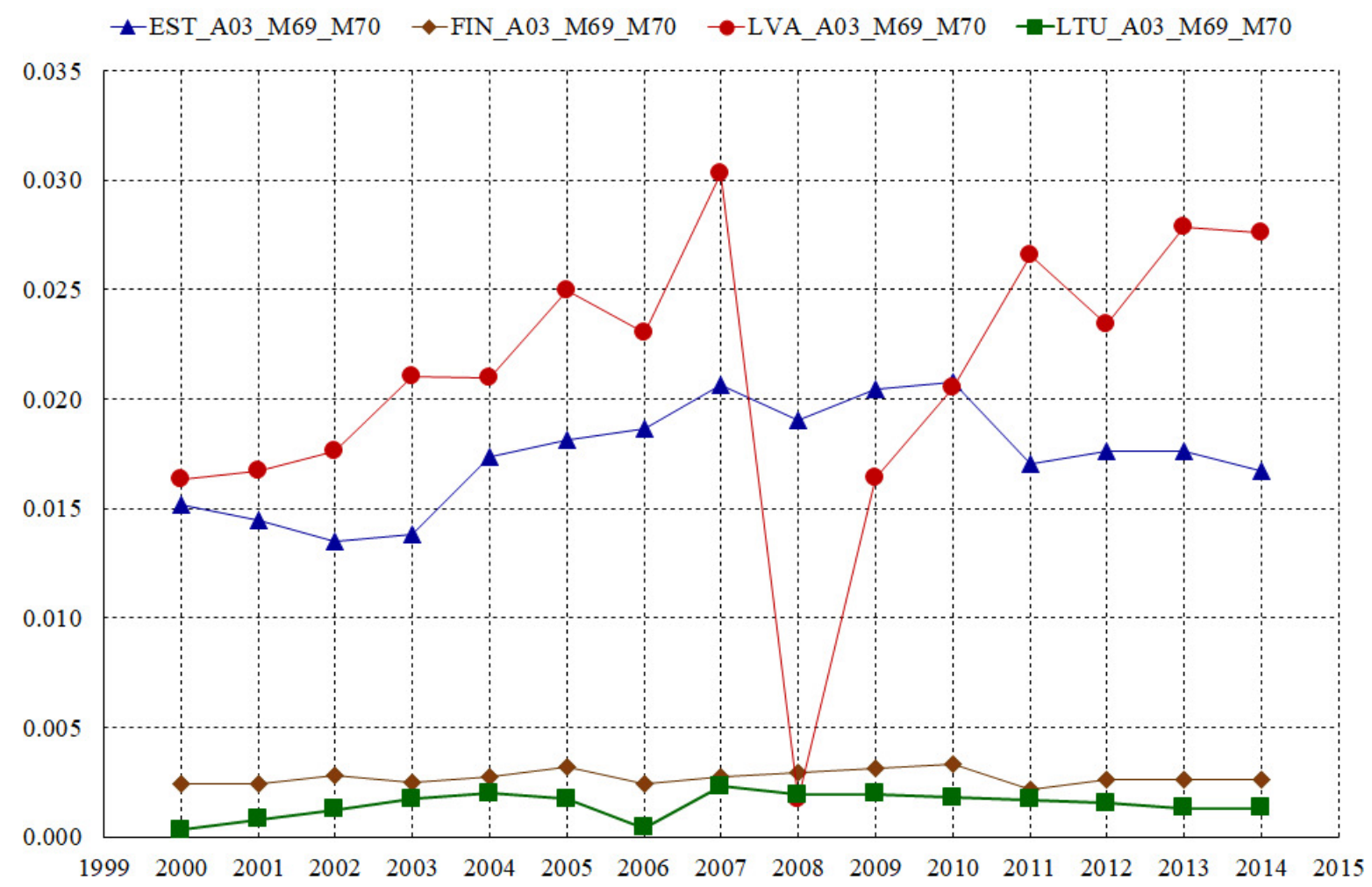

Fig. 8. Dynamics of industry's M69_M70 (Legal and accounting activities; activities of head offices; management consultancy activities) product intermediate consumption as part of A03 one monetary unit gross output

Figure 8 demonstrates notable differences in the intermediate expenses relating to M69_M70 (Legal and accounting activities; activities of head offices; management consultancy activities). The purchases of M69_M70 in LVA are much larger than in other countries of reference. In our opinion, alike the purchases from D35 (Electricity, gas, steam and air conditioning supply), the expensive purchases from M69_M70 also witness about internal corruptive processes.

Figure 9 demonstrates notable differences in the intermediate expenses relating to $\mathrm{C} 30$ (Manufacture of other transport equipment). What is the explanation for the fact that intermediate consumption of the product of C30 in 2014 in LVA is 0.0191, as compared to 0.0004 in EST, 0.0003 in FIN, 0.0054 in LTU? This requires further examination together with industry A03 and C30 experts. But right now we can only recommend to A03 managers to visit their Finnish colleagues and to learn their management success.

Figure 10 shows the intermediate expenses relating to C33 (Repair and installation of machinery and equipment), where the differences are not so huge.

The direct backward linkages summarize the results of intermediate average costs investigation. The average costs with respect to one monetary unit of gross output are the highest for the Latvian A03, namely, in 2014 this indicator was 0.5640. At the same time, DBL(EST, A03, 2014) $=0.4687$; DBL(FIN, A03, 2014) $=0.3466$; DBL $($ LTU, A03, 2014 $)=0.5158$.

5. Comparison and analysis of allocation coefficients.

Table 8 contains two arranged (from largest to smallest) excerpts from the allocation matrices G: arrangement by LVA indicators and arrangement by FIN indicators. We can observe differences among the ten biggest buyers of A03 products.

Let us consider the sales relating to industry I (Accommodation and food service activities): Latvian 0.0065 as compared to Finnish 0.1741 ; and sales relating to industry Q (Human health and social work activities): Latvian 0.0018 as compared to Finnish 0.0159. It appears to us that it is not difficult to explain these differences and to take in account the Finnish experience.

In our opinion, it is worth to investigate the reason of the difference between direct forward linkages in LVA and FIN: DFL(LVA, A03, 2014) $=0.2708$; DFL(FIN, A03, 2014) $=0.5424$. 
Further investigation is needed together with industry A03 experts in order to clarify the PESTILB environment and to elaborate upgraded management decisions.

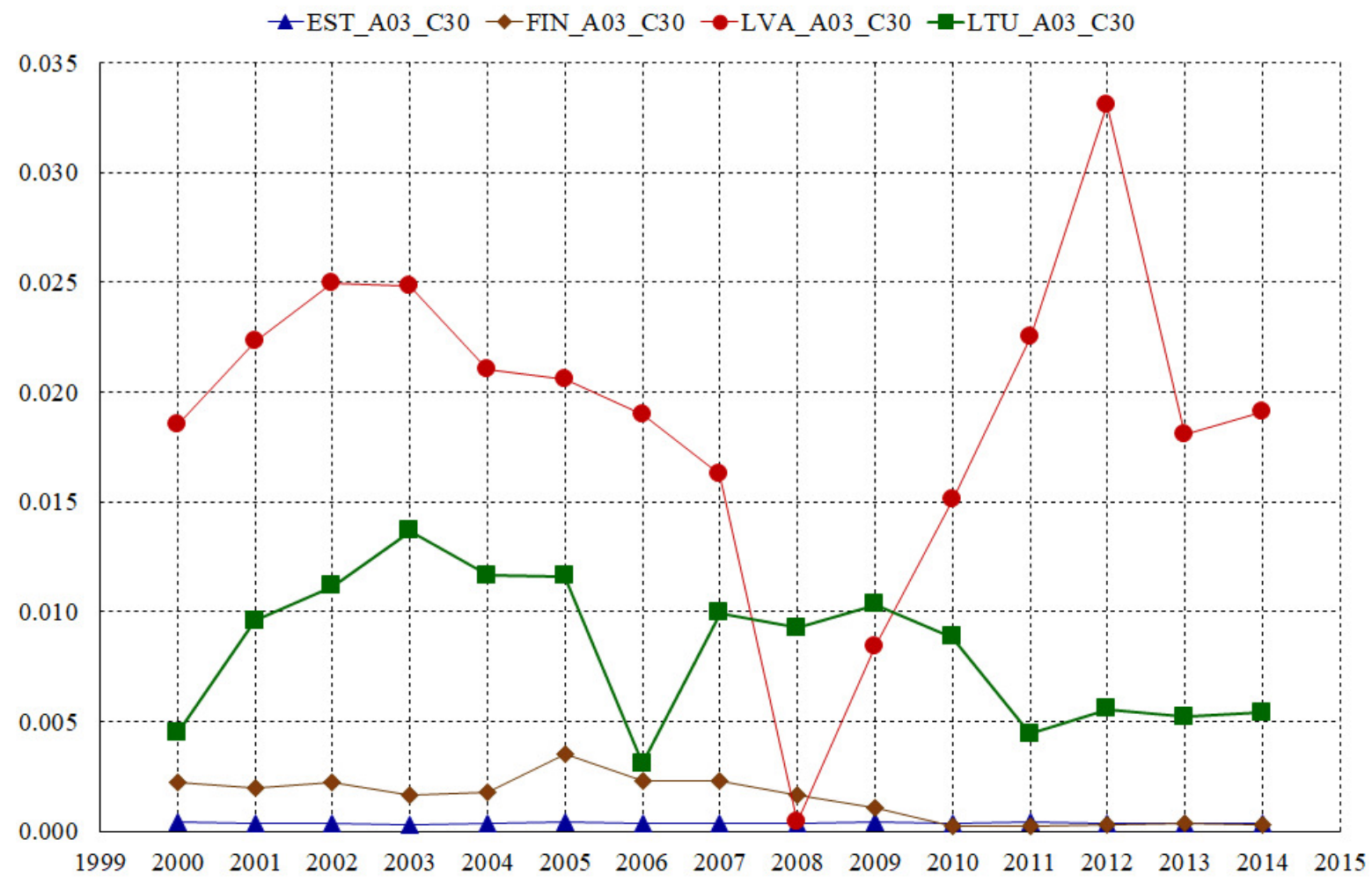

Fig. 9. Dynamics of industry's C30 (Manufacture of other transport equipment) product intermediate consumption as part of $\mathrm{A03}$ one monetary unit gross output

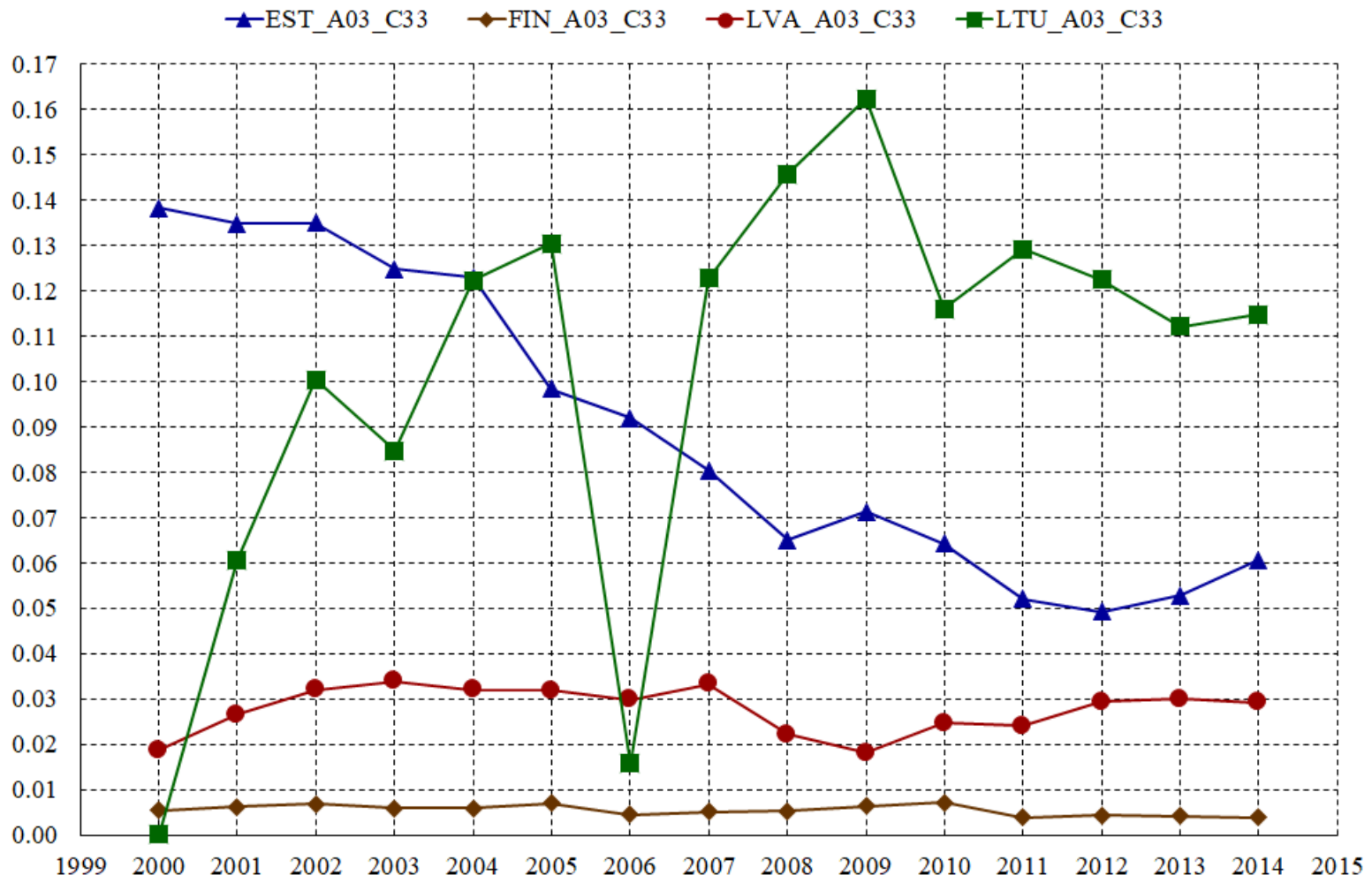

Fig. 10. Dynamics of industry's C33 (Repair and installation of machinery and equipment) product intermediate consumption as part of A03 one monetary unit gross output 
The industry's A03 ten biggest allocations coefficients for LVA and FIN (2014)

Table 8 (components of the vectors $G_{j}$.)

\begin{tabular}{|c|c|c|c|c|}
\hline Code & EST & FIN & LVA & LTU \\
\hline C10-C12 & 0.382 & 0.1535 & $\mathbf{0 . 1 6 0 3}$ & 0.5438 \\
\hline A03 & 0.0031 & 0.1184 & $\mathbf{0 . 0 1 5 4}$ & 0.0009 \\
\hline D35 & 0.001 & 0.0009 & $\mathbf{0 . 0 0 9 5}$ & 0.0001 \\
\hline H49 & 0.0019 & 0.0006 & $\mathbf{0 . 0 0 9 2}$ & 0.007 \\
\hline O84 & 0.002 & 0.009 & $\mathbf{0 . 0 0 8 5}$ & 0.0053 \\
\hline N & 0.001 & 0.0126 & $\mathbf{0 . 0 0 8 2}$ & 0.0024 \\
\hline F & 0.0018 & 0.0034 & $\mathbf{0 . 0 0 8 1}$ & 0.0009 \\
\hline I & 0.1238 & 0.1741 & $\mathbf{0 . 0 0 6 5}$ & 0.0006 \\
\hline L68 & 0.0016 & 0.0047 & $\mathbf{0 . 0 0 5}$ & 0.0002 \\
\hline G46 & 0.0013 & 0.0021 & $\mathbf{0 . 0 0 4 1}$ & 0.0027 \\
\hline
\end{tabular}

\begin{tabular}{|c|c|c|c|c|}
\hline Code & EST & FIN & LVA & LTU \\
\hline I & 0.1238 & $\mathbf{0 . 1 7 4 1}$ & 0.0065 & 0.0006 \\
\hline C10-C12 & 0.382 & $\mathbf{0 . 1 5 3 5}$ & 0.1603 & 0.5438 \\
\hline A03 & 0.0031 & $\mathbf{0 . 1 1 8 4}$ & 0.0154 & 0.0009 \\
\hline Q & 0.0021 & $\mathbf{0 . 0 1 5 9}$ & 0.0018 & 0.0046 \\
\hline N & 0.001 & $\mathbf{0 . 0 1 2 6}$ & 0.0082 & 0.0024 \\
\hline O84 & 0.002 & $\mathbf{0 . 0 0 9}$ & 0.0085 & 0.0053 \\
\hline H52 & 0.0026 & $\mathbf{0 . 0 0 7 8}$ & 0.0025 & 0.0017 \\
\hline P85 & 0.0047 & $\mathbf{0 . 0 0 7 1}$ & 0.0029 & 0.0002 \\
\hline R_S + T + U & 0.0039 & $\mathbf{0 . 0 0 6 6}$ & 0.0035 & 0.0024 \\
\hline J62_J63 & 0.0001 & $\mathbf{0 . 0 0 6}$ & 0.0009 & 0 \\
\hline DFL & 0.5453 & 0.5424 & 0.2708 & 0.588 \\
\hline
\end{tabular}

6. Comparison and analysis of the impact of A03 final demand increase on the total output required for equilibrium in the national economy.

Table 9 contains two arranged (from largest to smallest) excerpts from the Leontief inverse $\boldsymbol{\Lambda}$ : arrangement by LVA indicators and arrangement by FIN indicators. We can observe notable distinction in the national industries' necessary reaction to the A03 final demand increase in order to provide economic equilibrium in the national economy. For example, as it was expected, in LVA the big pressure is related to the pitifully famous Latvian industry D35 (Electricity, gas, steam and air conditioning supply). In LVA it is more than three times larger than in the other referred countries.

Surprisingly, the Latvia's A03 final demand increase shows impact of 0.0832 to the industry G46 (Wholesale trade, except of motor vehicles and motorcycles), when compared with 0.0134; 0.0046; 0.0090 in EST, FIN and LTU.

Table 9

Industry's A03 twelve biggest Leontief coefficients for LVA and FIN (2014) (components of the vectors $\Lambda_{j}$.)

\begin{tabular}{|c|c|c|c|c|}
\hline Code & EST & FIN & LVA & LTU \\
\hline A03 & 1.0034 & 1.1343 & $\mathbf{1 . 0 1 5 8}$ & 1.0010 \\
\hline G46 & 0.0134 & 0.0046 & $\mathbf{0 . 0 8 3 2}$ & 0.0090 \\
\hline D35 & 0.0157 & 0.0145 & $\mathbf{0 . 0 6 6 2}$ & 0.0219 \\
\hline H52 & 0.0758 & 0.0017 & $\mathbf{0 . 0 5 9 7}$ & 0.1639 \\
\hline H49 & 0.0205 & 0.0044 & $\mathbf{0 . 0 4 9 2}$ & 0.0282 \\
\hline C33 & 0.0649 & 0.0052 & $\mathbf{0 . 0 3 4 2}$ & 0.1238 \\
\hline M69_M70 & 0.0181 & 0.0028 & $\mathbf{0 . 0 3 2 9}$ & 0.0096 \\
\hline G47 & 0.0386 & 0.0053 & $\mathbf{0 . 0 2 7 5}$ & 0.0162 \\
\hline C10-C12 & 0.0104 & 0.0069 & $\mathbf{0 . 0 2 6 9}$ & 0.0023 \\
\hline A01 & 0.0027 & 0.0043 & $\mathbf{0 . 0 2 1 7}$ & 0.0010 \\
\hline L68 & 0.0187 & 0.0052 & $\mathbf{0 . 0 2 1 4}$ & 0.0690 \\
\hline F & 0.0065 & 0.0021 & $\mathbf{0 . 0 2 0 5}$ & 0.0060 \\
\hline TBL & 1.4240 & 1.2480 & $\mathbf{1 . 5 8 6 1}$ & 1.5870 \\
\hline
\end{tabular}

\begin{tabular}{|c|c|c|c|c|}
\hline Code & EST & FIN & LVA & LTU \\
\hline A03 & 1.0034 & $\mathbf{1 . 1 3 4 3}$ & 1.0158 & 1.0010 \\
\hline D35 & 0.0157 & $\mathbf{0 . 0 1 4 5}$ & 0.0662 & 0.0219 \\
\hline C19 & 0.0123 & $\mathbf{0 . 0 0 9 8}$ & 0.0020 & 0.0229 \\
\hline R_S + T + U & 0.0027 & $\mathbf{0 . 0 0 7 3}$ & 0.0023 & 0.0034 \\
\hline C10-C12 & 0.0104 & $\mathbf{0 . 0 0 6 9}$ & 0.0269 & 0.0023 \\
\hline G47 & 0.0386 & $\mathbf{0 . 0 0 5 3}$ & 0.0275 & 0.0162 \\
\hline L68 & 0.0187 & $\mathbf{0 . 0 0 5 2}$ & 0.0214 & 0.0690 \\
\hline C33 & 0.0649 & $\mathbf{0 . 0 0 5 2}$ & 0.0342 & 0.1238 \\
\hline G46 & 0.0134 & $\mathbf{0 . 0 0 4 6}$ & 0.0832 & 0.0090 \\
\hline H49 & 0.0205 & $\mathbf{0 . 0 0 4 4}$ & 0.0492 & 0.0282 \\
\hline A01 & 0.0027 & $\mathbf{0 . 0 0 4 3}$ & 0.0217 & 0.0010 \\
\hline N & 0.0262 & $\mathbf{0 . 0 0 4 1}$ & 0.0160 & 0.0080 \\
\hline
\end{tabular}

Tables 10 and 11 show that in EST, FIN, LVA, LTU the industry A03 has to be qualified as an industry with relatively small total backward linkage. This indicates a relatively small impact on the rest national industries caused by an increase in the final demand in A03, especially insignificant part of A03 in national economy is taken into account. Therefore, if the production capacity allows, then Latvia's A03 can increase its final demand. 
LVA industries with twelve biggest total backward linkages (TBL) and industries

Table 10 with twelve smallest total backward linkages

\begin{tabular}{|l|c|c|c|c|c|c|c|c|c|c|c|c|}
\hline Code & H52 & C19 & C16 & D35 & F & H51 & M73 & A02 & K65 & H49 & G46 & J58 \\
\hline TBL & 2.2395 & 2.2022 & 2.1677 & 2.0962 & 2.0953 & 2.0543 & 2.0234 & 1.9843 & 1.9606 & 1.8643 & 1.8290 & 1.8110 \\
\hline
\end{tabular}

\begin{tabular}{|c|c|c|c|c|c|c|c|c|c|c|c|c|}
\hline Code & J62_J63 & O84 & C29 & C28 & C17 & C22 & C27 & C25 & C26 & P85 & Q & M72 \\
\hline
\end{tabular}

\begin{tabular}{|l|l|l|l|l|l|l|l|l|l|l|l|l|}
\hline TBL & 1.4632 & 1.4436 & 1.4372 & 1.4203 & 1.3891 & 1.3765 & 1.3762 & 1.3351 & 1.3344 & 1.3150 & 1.2958 & 1.1499 \\
\hline
\end{tabular}

Table 11

FIN industries with twelve biggest total backward linkages (TBL) and industries with twelve smallest total backward linkages

\begin{tabular}{|c|c|c|c|c|c|c|c|c|c|c|c|c|}
\hline Code & C10-C12 & C16 & C17 & H52 & H51 & A01 & I & C24 & C18 & F & J58 & M74_M75 \\
\hline TBL & 2.2358 & 2.1191 & 2.0941 & 2.0621 & 2.0458 & 1.9144 & 1.8941 & 1.8873 & 1.8468 & 1.8024 & 1.7662 & 1.7647 \\
\hline
\end{tabular}

\begin{tabular}{|c|c|c|c|c|c|c|c|c|c|c|c|c|}
\hline Code & C29 & K65 & C13-C15 & C19 & Q & L68 & E36 & P85 & A02 & M72 & C21 & A03 \\
\hline TBL & 1.5067 & 1.4940 & 1.4719 & 1.4568 & 1.4458 & 1.4306 & 1.4151 & 1.3519 & 1.3388 & 1.3243 & 1.3161 & $\mathbf{1 . 2 4 8 0}$ \\
\hline
\end{tabular}

7. Elasticities of gross output (total) with respect to the final demand of A01, A02, A03 in the Baltic States and Finland in 2014.

According to the economic essence of Leontief's inverse the total backward linkage TBL, for instance, for the industry A03, means the following: TBL(A03) equals to the sum of required balanced growth of all national industries gross outputs in case, if the final demand of A03 increases by one monetary unit, when the final demand of all the other industries remains unchanged.

In mathematical form:

$$
\mathrm{FD}(\mathrm{A} 03) \uparrow \varepsilon \Rightarrow \mathrm{GO}(\text { total }) \uparrow[\varepsilon \cdot \mathrm{TBL}(\mathrm{A} 03)]
$$

for each real $\varepsilon$ in a proper interval.

Let

$\varepsilon=0.01 \cdot \mathrm{FD}(\mathrm{A} 03)$, then $\mathrm{FD}(\mathrm{A} 03) \uparrow[0.01 \cdot \mathrm{FD}(\mathrm{A} 03)] \Rightarrow \mathrm{GO}($ total $) \uparrow[0.01 \cdot \mathrm{FD}(\mathrm{A} 03) \cdot \mathrm{TBL}(\mathrm{A} 03)]$.

Consequently, elasticity of $\mathrm{GO}$ (total) with respect to the

$$
\mathrm{FD}(\mathrm{A} 03)=\mathrm{FD}(\mathrm{A} 03) \cdot \mathrm{TBL}(\mathrm{A} 03) / \mathrm{GO}(\text { total }) \text {. }
$$

Table 12 contains and Figure 11 depicts the elasticities of gross output (total) with respect to the final demand of the industries A01, A02, A03 in the Baltic States and Finland in 2014.

Table 12

Elasticities of Gross Output (total) with respect to the Final Demand of the industries A01, A02, A03 in the Baltic States and Finland in 2014

\begin{tabular}{|c|c|c|c|c|c|c|c|c|c|c|}
\hline \multirow{2}{*}{ Code } & TBL & TBL & TBL & FD & FD & FD & GO & $\begin{array}{c}\text { Elasticity } \\
\text { of } \\
\text { GO(total })\end{array}$ & $\begin{array}{c}\text { Elasticity } \\
\text { of } \\
\text { of (total })\end{array}$ & $\begin{array}{c}\text { Elasticity } \\
\text { of } \\
\text { of (total) }\end{array}$ \\
\cline { 2 - 11 } & A01 & A02 & A03 & A01 & A02 & A03 & total & A01 & A02 & A03 \\
\hline EST & 1.5849 & 1.6428 & 1.4240 & 606.63 & 219.16 & 49.54 & 54483.17 & 0.0176 & 0.0066 & 0.0013 \\
\hline FIN & 1.9144 & 1.3388 & 1.2480 & 2288.07 & 1466.27 & 110.64 & 513657.88 & 0.0085 & 0.0038 & 0.0003 \\
\hline LVA & 1.6921 & 1.9842 & 1.5861 & 1091.95 & 378.63 & 57.83 & 64725.66 & 0.0285 & 0.0116 & 0.0014 \\
\hline LTU & 1.4499 & 1.5070 & 1.5870 & 2213.41 & 268.81 & 26.35 & 85667.79 & 0.0375 & 0.0047 & 0.0005 \\
\hline
\end{tabular}

As it was expected, we can observe notable differences in the calculated elasticities among the three industries "Crop and animal production, hunting and related service activities", "Forestry and logging", "Fishing and aquaculture" because of differences in the final demand and total backward linkages. It indicates significant distinction in the national industries' necessary reaction to the final demand increase in order to provide economic equilibrium in the national economy.

However, the comparative aspect is again more interesting. 
Why Finland has the smallest elasticity as compared with Estonia, Latvia and Lithuania?

The reason is the more thrifty, more economical production in all these industries. Also the total backward linkages testify about it.

What about "Fishing and aquaculture"? Calculations indicate a small impact on the rest national industries caused by the value added increase in A03 in all referred countries. Namely, if the industry A03 is able to increase its final demand, when final demands of all the other industries remain unchanged, the required balanced growth of all national industries gross outputs to ensure economic equilibrium is absolutely realistic.

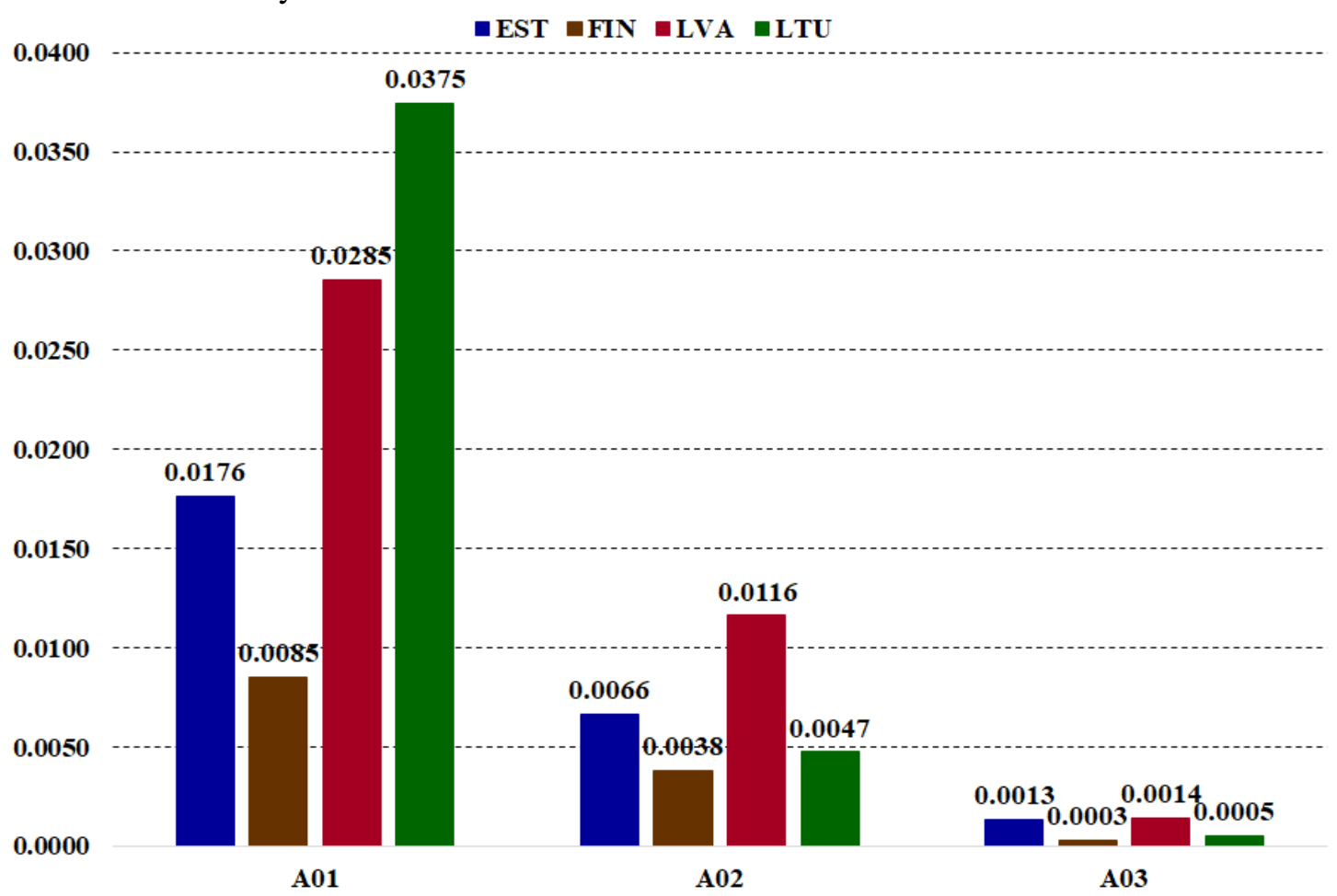

Fig. 11. Elasticities of gross output (total) with respect to the final demand of the industries A01, A02, A03 in the Baltic States and Finland in 2014

8. Comparison and analysis of the impact of industry's "Fishing and aquaculture" value added increase on the total output required for equilibrium in the national economy.

Table 13 contains two arranged (from largest to smallest) excerpts from the Ghosh inverse $\Gamma$ : arrangement by LVA indicators and arrangement by FIN indicators.

Table 13

Industry's "Fishing and aquaculture" ten biggest Gosh coefficients for LVA and FIN (components of the vectors $\Gamma_{j}$.)

\begin{tabular}{|c|c|c|c|c|}
\hline Code & EST & FIN & LVA & LTU \\
\hline A03 & 1.0034 & 1.1343 & $\mathbf{1 . 0 1 5 8}$ & 1.001 \\
\hline C10-C12 & 0.4321 & 0.2276 & $\mathbf{0 . 1 8 0 9}$ & 0.56 \\
\hline F & 0.0065 & 0.0164 & $\mathbf{0 . 0 1 9 4}$ & 0.0021 \\
\hline D35 & 0.0028 & 0.004 & $\mathbf{0 . 0 1 8 8}$ & 0.0005 \\
\hline H49 & 0.0049 & 0.0052 & $\mathbf{0 . 0 1 4 3}$ & 0.0092 \\
\hline I & 0.1452 & 0.2242 & $\mathbf{0 . 0 1 3}$ & 0.0033 \\
\hline N & 0.0061 & 0.023 & $\mathbf{0 . 0 1 1 6}$ & 0.0029 \\
\hline O84 & 0.0067 & 0.0244 & $\mathbf{0 . 0 1 1 5}$ & 0.0063 \\
\hline G46 & 0.0053 & 0.0146 & $\mathbf{0 . 0 0 9 9}$ & 0.005 \\
\hline H52 & 0.0074 & 0.02 & $\mathbf{0 . 0 0 9 9}$ & 0.0026 \\
\hline TFL & 1.7034 & 1.9393 & $\mathbf{1 . 3 7 8 7}$ & 1.6378 \\
\hline
\end{tabular}

\begin{tabular}{|c|c|c|c|c|}
\hline Code & EST & FIN & LVA & LTU \\
\hline A03 & 1.0034 & $\mathbf{1 . 1 3 4 3}$ & 1.0158 & 1.001 \\
\hline C10-C12 & 0.4321 & $\mathbf{0 . 2 2 7 6}$ & 0.1809 & 0.56 \\
\hline I & 0.1452 & $\mathbf{0 . 2 2 4 2}$ & 0.013 & 0.0033 \\
\hline Q & 0.0047 & $\mathbf{0 . 0 4 6 3}$ & 0.0031 & 0.0061 \\
\hline O84 & 0.0067 & $\mathbf{0 . 0 2 4 4}$ & 0.0115 & 0.0063 \\
\hline N & 0.0061 & $\mathbf{0 . 0 2 3}$ & 0.0116 & 0.0029 \\
\hline H52 & 0.0074 & $\mathbf{0 . 0 2}$ & 0.0099 & 0.0026 \\
\hline P85 & 0.0103 & $\mathbf{0 . 0 1 9 7}$ & 0.0048 & 0.0005 \\
\hline R_S + T + U & 0.0081 & $\mathbf{0 . 0 1 8 8}$ & 0.0055 & 0.0033 \\
\hline F & 0.0065 & $\mathbf{0 . 0 1 6 4}$ & 0.0194 & 0.0021 \\
\hline
\end{tabular}


The content of Table 13 confirms, from another point of view, the conclusion made before on the basis of Tables 10 and 11: the industry A03 in EST, LVA, LTU has to be qualified as industry with small total forward linkage: TFL(EST, A03, 2014) $=1.0034$; TFL(FIN, A03, 2014) =1.1343; TFL $(L V A$, A03, 2014 $)=1.0158 ;$ TFL $(L T U, A 03,2014)=1.0010$.

That conclusion indicates a small impact on the rest of national industries caused by the value added increase in A03. If the industry A03 is able to increase its value added, when value added of all the other industries remains unchanged, the required balanced growth of all national industries gross outputs is realistic.

\section{Conclusions}

1. The comparative analysis of value added created by the industry "Fishing and aquaculture" with respect to the industry's gross output in the Baltic States and Finland in the period of 2000-2014 demonstrates the comparative inefficiency of the Latvian industry.

2. The economic analysis shows that the most important point that caused the comparative inefficiency of the Latvian industry "Fishing and aquaculture" is the considerably higher intermediate costs per monetary unit of gross output. Besides that, also the inefficient allocation of the products of "Fishing and aquaculture" in the domestic economy is observed.

3. One of the possible tools to increase value added in the Latvian "Fishing and aquaculture" is expanding the final demand, because the final demand increase in this industry requires small balanced growth of all national industries gross outputs.

4. The rigorous micro-economical and technical analysis of the Latvian "Fishing and aquaculture" product average costs and product allocation in the domestic economy compared with Estonia, Finland and Lithuania would be useful.

5. Further investigation is needed together with industry "Fishing and aquaculture" experts in order to explain the most essential differences between the line of input-output indicators in order to elaborate proper managerial decisions.

\section{References}

[1] Proskina L., Pilvere I., Nipers A., Silovs M. Characteristics of the fishing industry in Latvia. Proceedings of the 2018 International Conference "Economic Science for Rural Development" No. 49, Jelgava, LLU, ESAF, 9-11 May, 2018, pp. 56-64. DOI: 10.22616/ESRD.2018.118

[2] Mickiewicz B., Brocki W. Employment and Wages in Fisheries of the Baltic Rim Countries. Proceedings of the 2018 International Conference "Economic Science for Rural Development" No. 48, Jelgava, LLU, ESAF, 9-11May, 2018, pp.186-94. DOI: 10.22616/ESRD.2018.084

[3] Viederyte R. Lithuanian Maritime Sector's Clustering Economic Impact Evaluation. Procedia Social and Behavioural Sciences, Vol. 156, 2014, pp. 292-297. DOI: 10.1016/j.sbspro.2014.11.191.

[4] Viederyte R. Maritime Sector Impact on the Economy of Lithuania. Economics and Management. Vol. 17, No. 1, 2012, pp. 244-249. DOI: 10.5755/j01.em.17.1.2274

[5] Ashyrov G., Paas T., Tverdostup M. The Input-Output Analysis of Blue Industries: Comparative Study of Estonia and Finland. University of Tartu. Faculty of Social Sciences. School of Economics and Business Administration, Working Paper Series, No. 109, 2018. 25 p. [online] [28.03.2020]. Available at: https://majandus.ut.ee/en/research/workingpapers

[6] Paas T., Tverdostup M. Ashyrov G. Assessment of the role of marine industries in the region. Plan4Blue, Final Report (Deliverable T.1.8.1), 2019, 86 p. [online] [28.03.2020]. Available at: https://www.syke.fi/download/noname/\%7BAC9F6185-E748-4F32-9D81-54B83A5A7D5B $\% 7 \mathrm{D} / 144424$

[7] Tverdostup, Maryna \& Paas, Tiiu. Economic Performance Analysis of Selected Blue Economy Sectors in Estonia and Finland. University of Tartu. Faculty of Social Sciences. School of Economics and Business Administration, Working Paper Series, No. 115, 2019, 24 p. [online] [28.03.2020]. Available at: https://majandus.ut.ee/en/research/workingpapers

[8] Jaunzems A. Methods of measuring industry total factor productivity within an input-output framework. 16th International Scientific Conference on Engineering for Rural Development, Proceedings, Volume 16, Jelgava, Latvia, 2017, pp. 383-392. 
[9] Jaunzems A. Comparative dynamic analysis of value added created by industry "forestry and logging" in the Baltic states and Finland. 17th International Scientific Conference on Engineering for Rural Development. Proceedings, Latvia, Jelgava, 2018, pp. 1019-1028.

[10] Jaunzems, A., Balode, I. Comparative dynamic analysis of value added created by industry "Crop and animal production, Hunting and related service activities" in the Baltic States and Finland. 18th International Scientific Conference Engineering for Rural Development, Jelgava, Latvia, 2019, pp. 1104-1117.

[11] Walras L. Éléments d'économie politique pure (1899, 4th ed.; 1926, éd. définitive).

[12] Walras L. Elements of Pure Economics, trans. William Jaffé. - Irwin, 1954.

[13]Leontief W. Input-Output Economics. Second Edition. - Oxford University Press. 1986, 436 p.

[14] Ghosh A. Input-Output Approach to an Allocation System. - Economica, Vol. 25, No. 1, 1958, pp. 58-64.

[15]Ronald E. Miller, Peter D. Blair. Input-Output analysis. Foundations and extensions. Second Edition. - Cambridge University Press, 2013, 750 p.

[16] Rose A., Miernyk, W. (1989). Input-output analysis: the first fifty years. - Economic Systems Research, 1(2), pp. 229-272.

[17] Applications of the Input-Output Framework. Editor Kakali Mukhopadhyay. - Springer Proceedings in Business and Economics. 2018. ISBN 978-981-13-1506-0 ISBN 978-981-131507-7 (eBook), DOI: 10.1007/978-981-13-1507-7.

[18] Thijs ten R. The use-make framework and the derivation of functional forms in production theory. - Economic Systems Research, vol. 31, NO 1, 2019, pp. 132-141.

[19]European Central Bank (ECB) Glossary [online] [28.03.2020]. Available at: http://www.ecb.europa.eu/home/glossary/html/glossv.en.html 